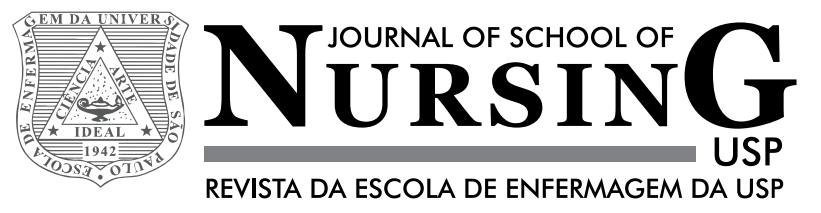

\title{
Direct cost of reprocessing cotton-woven surgical drapes: a case study
}

\section{Custo direto do reprocessamento de campos cirúrgicos de tecido de algodão: um estudo de caso}

Costo directo del reprocesamiento de campos quirúrgicos de tela de algodón: un estudio de caso

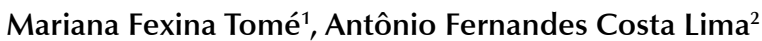

\footnotetext{
${ }^{1}$ Master's in Science, School of Nursing, Universidade de São Paulo, São Paulo, SP, Brazil.

${ }^{2}$ Doctorate Professor, Department of Professional Guidance, School of Nursing, Universidade de São Paulo. São Paulo, SP, Brazil.
}

\begin{abstract}
Objective: Identify the direct cost of reprocessing double and single cotton-woven drapes of the surgical LAP package. Method: A quantitative, exploratory and descriptive case study, performed at a teaching hospital. The direct cost of reprocessing cotton-woven surgical drapes was calculated by multiplying the time spent by professionals involved in reprocessing the unit with the direct cost of labor, adding to the cost of materials. The Brazilian currency $(\mathrm{R} \$)$ originally used for the calculations was converted to US currency at the rate of US $\$ 0.42 / \mathrm{R} \$$. Results: The average total cost for surgical LAP package was US $\$ 9.72$, with the predominance being in the cost of materials (US $\$ 8.70$ or $89.65 \%$ ). It is noteworthy that the average total cost of materials was mostly impacted by the cost of the cotton-woven drapes (US\$7.99 or $91.90 \%$ ). Conclusion: The knowledge gained will subsidize discussions about replacing reusable cotton-woven surgical drapes for disposable ones, favoring arguments regarding the advantages and disadvantages of this possibility considering human resources, materials, as well as structural, environmental and financial resources.
\end{abstract}

\section{DESCRIPTORS}

Protective Clothing; Product Packaging; Costs and Cost Analysis; Nursing. 


\section{INTRODUCTION}

Among the components of the surgical apparatus, surgical drapes constitute a barrier against micro-organism invasion at surgical sites, as well as protection for health professionals from exposure to body fluids. A standard package of reusable textiles named surgical $L A P$ is generally used for these purposes. The $L A P$ package is composed of six double woven cotton drapes, one single cotton linen and a double woven cotton linen for packaging, and all can be reprocessed.

A study examining the cumulative effect of cotton fabric made of $2 \times 1$ serge bonding, used in the manufacture of double cotton surgical drapes for packaging of medical items as an effective microbial barrier, and the multiple laundering and steam sterilization process effect on the barrier efficacy, correlating to the failure of microbial barrier due to physical changes of fabric characteristics which demonstrated from microbiological results that the effectiveness of the microbial barrier for equipment packaging only lasted a maximum of 65 reprocessing procedures. According to the authors, the reprocessing of these fabrics is a traditional practice which is supposed/inferred as low cost ${ }^{(1)}$.

Another study ${ }^{(2)}$ assessed the weight and the microbial barrier of single $100 \%$ cotton surgical drapes of $2 \times 1$ serge bonding, according to the Brazilian Association of Technical Standards $(\mathrm{ABNT})^{(3)}$. The study indicated that the effectiveness of the microbial barrier lasted until the fifth reprocessing cycle, when the fabrics lost an average of 6 to $15 \%$ of their initial weight. The researchers found more than five colony-forming units after the sixth cycle, demonstrating the barrier breakdown ${ }^{(2)}$.

Clinical practice recognizes that standard surgical $L A P$ packages do not completely attend the specificities of each surgery, thus its use varies depending on the size and the demand of the procedures performed. Depending on the surgical specialization, it is not unusual that up to four packages are used, or that a package is opened but only one of the seven drapes are used, causing waste and consequently increasing the cost of procedures.

In healthcare, waste is characterized by the unnecessary expense of resources, processes, products or procedures related to patient care. Its occurrence aggravates the difficulties already existing due to scarce human and material resources, including purchasing materials of questionable quality ${ }^{(4)}$.

Several companies sell basic or universal disposable kits that satisfy the majority of the surgical specializations due to the diversity of sizes and options, disposable kits with specific anatomical shapes and details for different surgeries (stickers that promote better adherence to the surgical site, presence of fenestrae and collection bags). Disposable drapes intended to cover the Mayo and instrument tables can integrate these kits or be sold individually. Therefore, the use of disposable materials could minimize waste.

A literature review seeking scientific evidence on the use of surgical gowns according to their composition (woven or non-woven fabric) included intervention studies investigating the contamination and/or infection of the surgical site with use of reusable or disposable surgical gowns. The authors reported difficulty finding studies on this issue of examining the effectiveness of single-use cotton surgical gowns, as only two of the studies revealed scientific evidence that there was no difference in contamination and/ or infection of surgical sites between woven and non-woven materials ${ }^{(5)}$.

Due to the complexity of dental-medical hospital apparatus reprocessing (AOMH in Portuguese), currently designated as health products by the Board Resolution RDC $15 / 2012^{(6)}$, in most institutions it is very difficult to determine the main processes to monitor and how to track their results. Therefore, planning and work adaptations are required in Central Sterile Services Department (CSSD), along with the use of indicators to evaluate their quality ${ }^{(7)}$.

It is the CSSD nurse's responsibility to consider the use of cleaning, disinfection and sterilization products, opting for technologies/products that save water and energy; and the use of reprocessed or recyclable packaging, also considering the environmental impact of certain products used ${ }^{(8)}$.

It would be possible to estimate the expenses a hospital organization would incur with the purchase of basic and specific surgical kits, but the lack of knowledge on the cost of reprocessing and reusing surgical cotton drapes prevents evaluating the economic impact that such changes would entail.

Although reducing health costs is a difficult task because of their nature, health decisions combined with economic principles are increasingly gaining strength, when considering the disproportion between available resources and the growing demands of society ${ }^{(9-11)}$. This is because cost management is an important aspect to be considered in achieving financial balance, and increasing accessibility without harming the quality of health services ${ }^{(12)}$.

In some public and private hospitals, nurses have decision-making power in allocating resources, assessing needs related to material, physical, human and financial resources; performing critical monthly analysis of unit costs, comparing budgeted and actual costs; and participating in budget forecasts for following years ${ }^{(13)}$.

It is noteworthy that nurses can improve health institutions performance by understanding costs, identifying and monitoring elements and processes steps that increase costs and those which can be eliminated without jeopardizing the quality and without compromising care demands ${ }^{(14)}$. Therefore, we developed this study in order to identify the direct costs of reprocessing the double and single surgical cotton drapes contained in LAP surgical package.

\section{METHOD}

This is a quantitative, exploratory and descriptive case study ${ }^{(15)}$, conducted at Hospital Santa Lucinda (HSL), after approval by the Research Ethics Committee of the applicant institution - CAAE: 23028113.0.0000.5392, number: 464.023 and under authorization of the Superintendent and the Academic Hospital Coordinator.

HSL, a teaching hospital of the Pontifícia Universidade de São Paulo, is located in the city of Sorocaba, in the 
countryside of São Paulo state. It has a surgical profile and serves approximately 50 municipalities in the region, totaling 2.2 million inhabitants. Of its 146 beds, 93 (63.7\%) are for patients from the Unified Brazilian Healthcare System (SUS), mostly occupied by clients in pre- and post-operative periods.

It performs an average of 700 surgeries/month in various specializations such as Orthopedics, general surgery, Cardiology, Plastic surgery, ENT, Ophthalmology, and Urology. Its physical structure is comprised of Primary Outpatient Clinics, Central Sterile Services Department - CSSD, Cardiology Center and Interventional Radiology, Adult Intensive Care Unit (ICU), Neonatal ICU, Surgical Center (SC), Obstetric and Gynaecology Center (OGC), Pediatrics, Dialysis Center and Renal Transplantation, Coronary Care Unit, Lithotripsy, Medical and Surgical Clinics.

All units/services that require $L A P$ packages for surgical demands are supplied by CSSD of the referred hospital, which assembles and sterilizes 40 to 60 packages/day. Drapes and packaging drapes are discarded after use into collecting bags and stored at the hospital's purge unit, to be collected later by the Linen Service staff (LS). An outsourced laundry service is responsible for the pickup, processing and return of the drapes to the LS. At the time of this research, the price of processed clothing was US\$0.83/ kilogram.

The LS works around the clock to control the input and output of hospital clothes/apparel, collecting used ones, receiving the processed material from the outsourced laundry and resupplying all units/services. It has one supervisor and eight maids.

Once a day the outsourced laundry collects used apparel and delivers clean material to the LS. Maids receive the processed material; they control the entry, count apparel by category (gowns, drapes, sheets, blankets/covers, camisoles, towels) and store them. Garments to be sterilized are forwarded to CSSD in the morning, in the afternoon and at night.

The CSSD, which is adjacent to the Surgical Center, also works 24/7 developing cleaning procedures, disinfection, sterilization and supplying HSL's units/services. Its physical structure consists of: the dressing room, the administrative room, the preparation area, the purging room, the sterilization room and the sterile material storage area. It has two ultrasonic washers, one heat-washing-disinfector, three pre-vacuum autoclaves and one low temperature hydrogen peroxide plasma sterilizer.

The professional staff is composed of a Nursing Coordinator, present at CSSD from 07:00a.m. to 4:00p.m., one nurse working from 3:00p.m. to 9:00p.m., 18 Technicians and three Nursing Assistants distributed throughout mornings, afternoons and nights to ensure proper functioning.

The steps and activities of the reprocessing process were mapped by observation actors not involved in LS and CSSD. Experienced professionals active in the study scenarios designed and validated the instrument. The instrument documented the consumption of materials (type and quantity) and time (timed with a stopwatch) spent by
Maids, Nursing Assistants (NA) and Nursing Technicians (NT) in order to calculate the direct costs.

Direct costs can be applied directly to products by measuring consumption. It is clearly quantifiable and identifiable with a product, service or Department/Unit/Section ${ }^{(16)}$. In hospitals, it consists of labor, materials and equipment directly used in the care process ${ }^{(14)}$.

Direct Labor Costs (DLC) are the costs of staff involved in product management, provided it is possible to identify who carried out the work and the amount of time spent for performing the task. Therefore, DLC constitutes wages, social security contributions, holiday provisions and 13th salary ${ }^{(16)}$.

The calculation of unit cost of DLC was based on average wages (salary, benefits and social charges), provided under the supervision of the Department of Human Resources of HSL in the frame of LS and CSSD professionals. We obtained US $\$ 1,017.39$ for maids, US $\$ 2,629.57$ for NA, and US\$1,704.22 for NT, for a contract workload of 144 hours/month. The salary category of NA was just justified to be greater than the NT category due to the first group of professionals having spent more time working in the Hospital. Since there is no distinction between NA and NT in carrying out steps/components activities of the process, we calculated the weighted average of the two categories (US\$ 1,836.41). So, time compensation per hour, minute, and second were: maids US\$ 7.07; US\$ 0.12; US\$ 0.002 and NA/ NT US $\$ 12.75$; US $\$ 0.21$ and US $\$ 0.0035$.

We clarify that we did not count the DLC of professionals involved in buying and receiving new drapes because it does not carry out a direct action on the object of study. Also, for the DLC of LS workers who collect used linens, it was not possible to estimate the amount of surgical drape components in the collection bags for the outsourced laundry along with other items of clothing used in Units/Services.

The cost of materials for making the $L A P$ packages based on the last three purchases were provided by the Coordination of Supply Inventory Sector, the Purchasing Department and the Coordination of Consultations.

We used the weight of clean fabric drapes to calculate the direct cost, because the weight after use varies according to each surgical procedure. There was no consensus obtained from the experienced professionals working in the LS on the estimate of the maximum number of reprocessing for these drapes, we considered 65 reuses for double drapes ${ }^{(1)}$ and five for single drapes ${ }^{(2)}$. The cost of reprocessing outsourced laundry increased according to the dry weight of the surgical drape.

To estimate the average monthly surgical $L A P$ package consumption and estimate average monthly consumption of surgical drape kits, surgical drapes and individual disposable drapes for auxiliary tables, they were grouped into surgeries/ procedures, according to the surgical specializations performed at HSL. For this group, we used the statistical data for three typical months of SC operations (September to November 2013) and counted with the collaboration of SC and CSSD Nursing Coordinators who have clinical experience and effective participation in surgical planning. Thus, 
we found a monthly average of 1,139 surgeries/procedures, with 639 surgeries, 243 deliveries (normal and caesarean sections) and 257 hemodynamic examinations.

The SC and CSSD helped in estimating the number of LAP packages the Nursing Coordinators needed by specialization, and established the type and the amount of disposable surgical drape kits, individual disposable drapes and table drapes needed to replace them. In order to estimate the values for these materials, they consulted the nine most wellknown suppliers in the market, and received 5 responses.

The direct cost of reprocessing the cotton fabric components of $L A P$ package surgical drapes was calculated by multiplying the (clocked) time spent by Maids, NA and NT with the unit cost of the DLC, adding to the cost of materials.

All values of the Brazilian currency $(R \$)$ originally used in this study were converted to American currency (US\$) based on the conversion rate of $\mathrm{R} \$ 1.00=\mathrm{US} \$ 0.42$ (02.10.2014).

\section{RESULTS}

Table 1 shows the average time spent by Maids in seconds in conducting the component activities of the steps for receiving clothing in the LS; assembling and sterilizing the surgical $L A P$ packet; $L A P$ surgical package storage and its respective cost, considering the manufacturing cost of a surgical $L A P$ package.

The reception of clothes step in the LS activity that spent the most time (104 seconds) and with the highest cost for Maid DLC (US\$ 0.21) was the removal of the drapes from plastic bags, the input control and storage.

With regard to assembly and sterilization of a $L A P$ package, the activity that took the longest for the NA/ NT was the reviewing the folds and integrity of the eight drapes, and introduction of the chemical integrator (104 seconds) which represented the highest cost (US\$0.36).

The storage for the LAP package corresponded to the step with the smallest time spent, due to the fact that a fully loaded autoclave containing ten packages is very quick to unload and their packaging is in the storage side of the sterilization room.
The data in Table 2 indicate the cost and amount of materials used for assembling and sterilizing a surgical $L A P$ package. The unit cost of surgical drapes added to the estimated cost of 65 reuses for double drapes, and five reuses for single drapes, added to the cost of reprocessing done by outsourced laundry (US $\$ 0.83 / 1000 \mathrm{~g}$ ) according to their weight (double drapes 1.80 x 1.60m - 800g; double drapes for packaging $1.00 \times 1.00 \mathrm{~m}-580 \mathrm{~g}$ and single drapes 1.60 x 90 - 400g).

As expected, the unit and the total costs of surgical drapes (double, double packing and single) were most impacted in the total cost of materials for end $L A P$ package (US\$ 7.98), especially the double drapes because they needed six units and single drapes due to the limiting number of only six reuses.

In relation to consumables, the chemical integrator had the highest cost (US\$0.58/unit) and the cost of using of biological indicator was not accounted for in the Bowie Dick test for routine serum procedures in the CSSD.

Table 2 - Distribution of the cost and quantity of materials used in the assembly and sterilization of surgical $L A P$ package - São Paulo, SP, Brazil, 2014.

\begin{tabular}{|c|c|c|c|}
\hline Materials & $\begin{array}{c}\text { Unitary } \\
\text { cost } \\
\text { US\$ }\end{array}$ & $\begin{array}{l}\text { Quantity } \\
\text { per surgical } \\
\qquad A P\end{array}$ & $\begin{array}{l}\text { Total } \\
\text { Cost } \\
\text { US\$ }\end{array}$ \\
\hline $\begin{array}{l}\text { Double ply/layer Drapes } \\
1.80 \times 1.60 \mathrm{~m}\end{array}$ & 0.88 & 06 units & 5.29 \\
\hline $\begin{array}{l}\text { Double ply/layer Drapes for } \\
\text { Packaging } 1.00 \times 1.00 \mathrm{~m}\end{array}$ & 0.69 & 01 unit & 0.69 \\
\hline $\begin{array}{l}\text { Single layer/ply drapes } \\
1.60 \times 90 \mathrm{~m}\end{array}$ & 2.00 & 01 unit & 2.00 \\
\hline $\begin{array}{l}\text { Autoclave Tape } \\
19 \mathrm{~mm} \times 30 \mathrm{~m}\end{array}$ & $\begin{array}{c}0.09 \\
(100 \mathrm{~cm})\end{array}$ & $40 \mathrm{~cm}$ & 0.04 \\
\hline $\begin{array}{l}\text { Hospital Masking Tape } \\
16 \mathrm{~mm} \text { x 50m - m332 }\end{array}$ & $\begin{array}{c}0.03 \\
(100 \mathrm{~cm})\end{array}$ & $240 \mathrm{~cm}$ & 0.06 \\
\hline $\begin{array}{l}\text { Double-sided adhesive label } \\
\text { with class } 1 \text { chemical indicator }\end{array}$ & 0.04 & 01 unit & 0.04 \\
\hline Class 6 chemical integrator & 0.58 & 01 unit & 0.58 \\
\hline Total & & & 8.70 \\
\hline
\end{tabular}

Table 1 - Distribution of the time and cost of DLC for Maids and NA/NT, according to the steps/activities for making a surgical LAP package - São Paulo, SP, Brazil, 2014.

\begin{tabular}{|c|c|c|}
\hline Steps/Activities & $\begin{array}{l}\text { Average time spent per } \\
\text { surgical LAP (seconds) }\end{array}$ & $\begin{array}{l}\text { Labor Cost per } \\
\text { person US\$ }\end{array}$ \\
\hline $\begin{array}{l}\text { Gowns and Drapes reception at } L S \text { : removing items out of plastic sealed bags; controlling } \\
\text { stock; storing items by category; assembling the dressing carts and transporting items to CSSD. }\end{array}$ & 148 & 0.30 \\
\hline \multicolumn{3}{|l|}{ DLC of Maids } \\
\hline $\begin{array}{l}\text { Assembly and sterilization of surgical LAP package: receiving items from LS; separating } \\
\text { drapes for LAP package assembly; review/checking folds and drapes integrity (eight units) and } \\
\text { introducing a chemical integrator; packing drapes with autoclave tape and masking tape to } \\
\text { identify the packages; establishing autoclave loads; listing all materials inserted into autoclave } \\
\text { on Sterilization Control and labeling all LAP packages (tracking); introducing load into the } \\
\text { autoclave, programing and initiating the sterilization cycle. }\end{array}$ & 198 & 0.69 \\
\hline $\begin{array}{l}\text { Storage of surgical LAP packages: unloading of autoclave onto dressing carts and storing LAP } \\
\text { packages } \\
\text { DLC of NA/NT }\end{array}$ & 09 & 0.03 \\
\hline Total DLC for maids and NA/NT & 355 & 1.02 \\
\hline
\end{tabular}


Table 3 shows that the average total cost, with the DLC for Maids and NA/NT and material for making a surgical $L A P$ package totaled US\$9.72 (100\%).

Table 3 - Distribution of the DLC for Maids, Nursing Assistants/ Technicians and materials needed, according to the steps for manufacturing a surgical $L A P$ package - São Paulo, SP, Brazil, 2014.

\begin{tabular}{lcccc}
\hline Steps & $\begin{array}{c}\text { DLC per } \\
\text { person } \\
\text { US\$ }\end{array}$ & $\begin{array}{c}\text { Material } \\
\text { Cost } \\
\text { US\$ }\end{array}$ & $\begin{array}{c}\text { Total } \\
\text { Cost } \\
\text { US\$ }\end{array}$ & $\%$ \\
\hline $\begin{array}{l}\text { Clothing reception at LS } \\
\begin{array}{l}\text { Assembly and sterilization } \\
\text { of surgical LAP package }\end{array}\end{array}$ & 0.30 & - & 0.30 & 3.09 \\
$\begin{array}{l}\text { Storage of surgical LAP } \\
\text { package }\end{array}$ & 0.03 & 8.70 & 9.39 & 96.60 \\
\hline Total & $\mathbf{1 . 0 2}$ & $\mathbf{8 . 7 0}$ & $\mathbf{9 . 7 2}$ & $\mathbf{1 0 0 . 0}$ \\
\hline
\end{tabular}

In the composition of the average total cost, the assembly and sterilization step of the surgical $L A P$ package was the most representative to US $\$ 9.39$, with the cost of the materials having the most impact at (US\$8.70) 89.51\%.

Monthly average consumption was estimated at 1,439 surgical $L A P$ packages in surgeries/procedures for 14 specializations performed at HSL, totaling US $\$ 13,987.08$. The Hemodynamics, Orthopedics and Obstetrics accounted for the biggest average monthly consumption of $L A P$ packages (753), with the largest impact on representing an estimated average monthly cost of $52.32 \%$.

Table 1 depicts the variation in prices of surgical kits, disposable surgical drapes and individual disposable drapes for auxiliary tables available from five companies. The average cost according to the type of kit/individual drapes required was taken from this information if there was a proposal to replace surgical $L A P$ packages being used in HSL.

Chart 1 - Distribution of minimum, maximum and average cost of surgical kits, surgical drapes and individual disposable drapes for auxiliary tables, according to the five suppliers - São Paulo, SP, Brazil, 2014.

\begin{tabular}{lccc}
\hline Kit/Individual drapes & $\begin{array}{c}\text { Minimum } \\
\text { Cost US\$ }\end{array}$ & $\begin{array}{c}\text { Maximum } \\
\text { Cost US\$ }\end{array}$ & $\begin{array}{c}\text { Average } \\
\text { Cost US\$ }\end{array}$ \\
\hline Individual surgical drapes & 2.86 & 4.00 & 3.26 \\
Individual table drapes & 1.81 & 9.11 & 6.67 \\
Hemodynamics/Angiography & 14.28 & 25.20 & 20.57 \\
Hands and extremities & 21.00 & 30.24 & 26.16 \\
Ophthamology & 4.70 & 10.75 & 7.96 \\
Orthopedics & 25.20 & 31.98 & 28.37 \\
ENT & 23.10 & 25.96 & 24.99 \\
C-section Delivery & 20.92 & 29.40 & 25.26 \\
Normal Delivery & 17.42 & 26.04 & 23.13 \\
Universal & 20.75 & 30.72 & 26.18 \\
Urology/Proctology/ & 25.20 & 30.66 & 27.10 \\
Gynecology & & & \\
\hline
\end{tabular}

Table 4 below demonstrates the average monthly cost related to the consumption of surgical kits, disposable surgical drapes and individual disposable side table drapes, to meet the various specializations, amounting to US $\$ 29,127.15$ (100.00\%).

Table 4 - Distribution of the total estimated average monthly consumption of surgical kits, surgical drapes and individual disposable auxiliary table drapes, and their cost according to the average of surgeries performed in HSL from September to November 2013 - São Paulo, SP, Brazil, 2014.

\begin{tabular}{lccc}
\hline Disposable Materials & $\begin{array}{c}\text { Average } \\
\text { consumption } \\
\text { (units) }\end{array}$ & $\begin{array}{c}\text { Total Cost } \\
\text { US\$ }\end{array}$ & $\%$ \\
\hline Surgical Kits & 1,167 & $27,937.98$ & 95,92 \\
Individual table drapes & 169 & $1,127.23$ & 3,87 \\
Individual surgical drapes & 19 & 61.94 & 0,21 \\
\hline Total & $\mathbf{1 , 3 5 5}$ & $\mathbf{2 9 , 1 2 7 . 1 5}$ & $\mathbf{1 0 0 , 0 0}$ \\
\hline
\end{tabular}

\section{DISCUSSION}

In the CSSD, a nurse's managerial performance is essential to the work process efficiency and to establish the measures necessary for forecasting and the provision of human, material and structural resources, in order to assure the quality of customer support ${ }^{(17)}$. The managerial role requires the nurse to have knowledge on the principles of cost accounting to support rational decision-making and the arguments for negotiating with the hospital administrators, in addition to having specific technical and scientific knowledge.

The average cost of US $\$ 8.70$ (89.51\%) for the materials integrated in the surgical $L A P$ package, mainly related to the double and single drapes, was the most impactful in the composition of the direct processing cost (US\$9.72), similar to what was found in studies that demonstrated the predominance of material costs in relation to DLC involving staff $^{(18-20)}$.

According to RDC $15^{(6)}$, the reuse of repaired drapes with patches or mended cotton, presence of holes, tears, fabric wear or any impaired barrier function are not allowed when they are used as packaging. Although this resolution refers to the double drapes for packaging, all cotton drapes in HSL are discarded regardless of how many times they have been reprocessed when characteristics that compromise the microbial barrier function are present. Given that the actual number of times that these drapes are used in the hospital is still unknown, it appears that the limit number of reuses may be different, or even less, than what is recommended in the literature ${ }^{(1-2)}$.

The estimated unit cost of the surgical drapes was calculated by adopting their weight before use (clean), but the amount charged by outsourced laundry next to the HSL is based on the weight after use, which is quite variable considering the specifics of each surgical procedure in relation to the volume of fluids, secretions and liquids.

Some surgical procedures performed in Urology, Gynecology and Orthopedics such as Transurethral Resection (TUR) surgery, Hysteroscopy and Arthroscopy, require continuous irrigation fluid and generate large volumes of fluids which are absorbed by tissue drapes, as well as large sized surgeries that have heavy bleeding. Thus, the drapes 
used in these procedures have increased weight and therefore a higher amount to be paid by the HSL to the outsourced laundry service.

The Hemodynamics, Orthopedics, Obstetrics and Plastic Surgery specializations which had the highest average monthly consumption of $L A P$ packages and the higher cost, also represent the greatest financial impact if there was the replacement of $L A P$ packages for disposable surgical kits.

In HSL, standard surgical LAP packages also do not meet the specificity of all surgical specializations, generating waste arising from using them in proceedings in which seven drapes would not be needed during it. Therefore, the use of disposable kits specific for each type of surgery, table drapes and individual disposable surgical drapes could be an alternative to minimize the occurrence of waste. Some types of disposable kits have drapes for collecting bags for storage of fluid volume generated during certain surgical procedures, which facilitates their disposal.

Regardless of the nature of the health organization being public or private, waste aggravates existing difficulties due to scarce resources, and so it is imperative to adopt measures/strategies for minimizing waste ${ }^{(4)}$.

It should be noted that the calculation of consumption costs of surgical kits and disposable drapes was based on the average of the values obtained from five suppliers without any kind of economic negotiation, which would occur from establishing a provision to be gained if the HSL opted for adopting them.

The study was not focused on comparing the costs attributed to reprocessing the fabric of surgical drapes in relation to the cost of their replacement by disposable surgical kits, as we could not identify the total cost of this process due to lack of information that would enable the measuring the indirect costs.

Until a few years ago, estimating the indirect cost or lack of it did not compromise the cost of products and services, as there was already a predominance of labor cost and materials directly allocated to a particular product or service. However, with technological advances indirect costs tend to have higher a share in total spending, thereby declining the direct costs within an organization. Thus, the lack of knowledge on indirect costs is a problem for organizations because there is no security of their ownership to costing objects and their behavior towards them ${ }^{(21)}$.
A study ${ }^{(22)}$ with the overall objective to apply the method of Costing Based on Activities in CSSD of a teaching hospital presented the total direct and indirect cost of each type of cycle / load and product groups for sterilization and disinfection as part of the results, having obtained the unit cost of the type of cycle / load for the objects of study. The total cost for the Saturated Vapor Pressure (SVP) sterilization amounted to US $\$ 413,743.64$, with the direct cost being US\$17,270.43 (4\%) and the indirect cost US\$396,473.20 (96\%). In addition to costing per cycle / charge, our data allowed for the identification of the unit cost per product group. The total cost identified for the sterilization of clothes by SVP was US $\$ 78,745.30$, of which US $\$ 15,740.90$ (20\%) represented the direct costs and US\$63,004.06 (80\%) represented indirect. This research showed the importance of indirect costing in the composition of the total cost of a CSSD.

From this perspective, the systematization of information that subsidizes the calculation of the indirect costs of reprocessing surgical $L A P$ packages would be crucial in the context of HSL to enable the comparison of the total cost compared to the costs of buying disposables.

However, in addition to the financial aspects involved in the choice of clothing for the surgical garment, in this case, surgical drapes, it is essential to consider the environmental impact of waste generated by an increase of disposables, since its use would increase the amount of Group A infectious waste production (material which came in contact with biological fluid) ${ }^{(23)}$, and consequently, the costs for their treatment (disinfection, sterilization or incineration).

\section{CONCLUSION}

The achievement of this single case study enabled the direct cost of the steps and their related activities to the reprocessing process of double and single cotton drapes, pieces of the surgical LAP packages used in a teaching hospital, amounting to a total of US $\$ 9.72$.

The knowledge gained will subsidize preliminary discussions on the economic feasibility of replacing reusable cloth drapes with disposable drapes, favoring to sustain arguments regarding the advantages and disadvantages of this possibility, considering the efficiency of human, material, structural, environmental and financial resources.

\section{RESUMO}

Objetivo: Identificar o custo direto do reprocessamento de campos de tecido de algodão, duplos e simples, integrantes do pacote de LAP cirúrgico. Método: Estudo de caso quantitativo, exploratório-descritivo, realizado em um hospital de ensino. Calculou-se o custo direto multiplicando-se o tempo despendido por profissionais envolvidos no reprocessamento pelo custo unitário da mão de obra direta, somando-se ao custo dos materiais. A moeda brasileira $(\mathrm{R} \$)$ utilizada originalmente para os cálculos foi convertida para a moeda norte-americana pela taxa de US\$ 0.42/R \$. Resultados: O custo total médio, por pacote de LAP cirúrgico, foi de US\$ 9.72, com predominância do custo com materiais (US\$ 8.70) 89.65\%. Destaca-se que o custo total médio dos materiais recebeu forte impacto dos custos dos campos de tecido de algodão (US\$ 7.99) 91.90\%. Conclusão: O conhecimento obtido subsidiará discussões sobre a substituição de campos de tecido reutilizáveis por campos descartáveis, favorecendo argumentações relativas às vantagens e desvantagens dessa possibilidade considerando os recursos humanos, materiais, estruturais, ambientais e financeiros.

\section{DESCRITORES}

Roupa de Proteção; Embalagem de Produtos; Custos e Análise de Custo; Enfermagem. 
RESUMEN

Objetivo: Identificar el costo directo del reprocesamiento de campos de tela de algodón, dobles y sencillos, integrantes del paquete de LAP quirúrgico. Método: Estudio de caso cuantitativo, exploratorio-descriptivo, llevado a cabo en un hospital de enseñanza. Se calculó el costo directo multiplicándose el tiempo empleado por los profesionales involucrados en el reprocesamiento por el costo unitario de la mano de obra directa, sumándose al costo de los materiales. La moneda brasileña $(\mathrm{R} \$)$ utilizada originalmente para los cálculos se convirtió en moneda estadounidense a la tasa de US\$ 0.42/R R. Resultados: El costo total medio, por paquete de LAP quirúrgico, fue US\$ 9.72, con predominancia del costo con materiales (US\$ 8.70), el 89.65\%. Se destaca que el costo total medio de los materiales recibió fuerte impacto de los costos de los campos de tela de algodón (US\$7.99), el 91.90\%. Conclusión: El conocimiento obtenido subsidiará discusiones acerca del reemplazo de campos de tela reutilizables por campos desechables, favoreciendo argumentaciones relativas a las ventajas y desventajas de dicha posibilidad al considerarse los recursos humanos, materiales, estructurales, ambientales y financieros.

\section{DESCRIPTORES}

Ropa de Protección; Embalaje de Productos; Costos y Análisis de Costo; Enfermería.

\section{REFERERENCES}

1. Rodrigues E, Levin AS, Sinto SI, CF Mendes, Barbosa B, Graziano KU. Evaluation of the use and re-use of cotton fabrics as medical and hospital wraps. Braz J Microbiol. 2006;37(2):113-16.

2. Burgatti JC, Possari JF, Moderno AMB. Avaliação da barreira microbiana do campo cirúrgico de algodão. Rev SOBECC. 2004;9(1):24-32.

3. Associação Brasileira de Normas Técnicas. ABNT NBR 14028/1997. Roupa hospitalar - confecção de campo duplo. Rio de Janeiro: ABNT; 1997.

4. Castilho V, Castro LC, Couto AT, Maia FOM, Sasaki NY, Nomura FH, et al. Survey of the major sources of waste in the health care units of a teaching hospital. Rev Esc Enferm USP. 2011;45(n.esp):1613-20.

5. Burgatti JC, Lacerda RA. Systematic review of surgical gowns in the control of contamination/surgical site infection. Rev Esc Enferm USP. 2009;43(1):237-44.

6. Brasil. Ministério da Saúde; Agência Nacional de Vigilância Sanitária. Resolução da Diretoria Colegiada - RDC n. 15, de 15 de março de 2012. Dispõe sobre requisitos de boas práticas para o processamento de produtos para a saúde e dá outras providências [Internet]. Brasília; 2012 [citado 2014 out. 12]. Disponível em: http://bvsms.saude.gov.br/bvs/saudelegis/anvisa/2012/rdc0015_15_03_2012.html

7. Calicchio LG, Santos FP, Silva CPR. Indicadores de monitoramento em Centro de Material e Esterilização. In: Leão ER, Silva CPR, Alvarenga DC, Mendonça SHF. Qualidade em saúde e indicadores como ferramenta de gestão. São Caetano do Sul: Yendis; 2008. p.281-93.

8. Psaltikidis EM. Desafios atuais e futuros para a Central de Materiais e Esterilização [Internet]. São Paulo; 2013 [citado 2014 out. 04]. Disponível em: http://www.nascecme.com.br/artigos/Desafios\%20atuais\%20e\%20futuros\%20para\%20a\%20CME\%20-\%20final.pdf

9. Raschka S, Dempster L, Bryce E. Health economic evaluation of an infection prevention and control program: are quality and patient safety programs worth the investment? Am J Infect Control. 2013;41(9):773-7.

10. McDermott K. Lowering the cost of health care: the West Health initiative. Am J Prev Med. 2013;44(1 Suppl 1):S51-3.

11. Jha AK, Orav EJ, Epstein AM. Public reporting of discharge planning and rates of readmissions. N Engl J Med. 2009;361(27):2637-45.

12. Castilho V, Mendes KGL, Jericó MC, Lima AFC. Gestão de custos em Serviços de Enfermagem. Programa de Atualização em Enfermagem. Rev Gestão. 2012;2(1)1:51-73.

13. Zunta RSB, Castilho V. Billing of nursing procedures at an intensive care unit. Rev Latino Am Enfermagem. 2011;19(3):573-80.

14. Castilho V, Fugulin FMT, Gaidzinski RR. Gerenciamiento de costos en los servicios de enfermería. In: Kurcgant P, organizadora. Gerenciamiento en enfermería. $2^{a}$ ed. Rio de Janeiro: Guanabara Koogan; 2010. p. 169-80.

15. Yin RK. Estudo de caso: planejamento e método. $4^{\mathrm{a}}$ ed. Porto Alegre: Bookman; 2010.

16. Martins E. Contabilidade de custos. $10^{a}$ ed. São Paulo: Atlas; 2010.

17. Silva AC, Aguiar BGC. O enfermeiro na central de material e esterilização: uma visão das unidades consumidoras. Rev Enferm UERJ [Internet]. 2008 [citado 2014 out. 12];16(3):377-81. Disponível em: http://www.facenf.uerj.br/v16n3/v16n3a13.pdf

18. Psaltikidis EM, Graziano KU, Frezatti F. Cost analysis of reprocessing disposable forceps used in video-assisted surgery. Rev Latino Am Enfermagem. 2006;14(4):593-600.

19. Lima AFC, Castilho V, Fugulin FMT, Silva B, Ramin NS, Melo TO. Costs of most frequent nursing activities in highly dependent hospitalized patients. Rev Latino Am Enfermagem. 2012;20(5):880-7.

20. Secco LMD, Castilho V. Expenditure survey on continued veno-venous hemodialysis procedure in the intensive care unit. Rev Latino Am Enfermagem. 2007;15(6):1138-43.

21. Gonçalves MA, Zac Jl, Amorim CA. Gestão estratégica hospitalar: aplicação de custos na saúde. R Adm FACES J. 2009;8(4):161-79.

22. Jericó MC, Castilho V. Cost management: the implementation of the activity-based costing method in central sterilizing services. Rev Esc Enferm USP [Internet]. 2010 [cited 2014 Oct 12];44(3):745-52. Available from: http://www.scielo.br/pdf/reeusp/v44n3/en_28.pdf

23. Brasil. Ministério do Meio Ambiente; Conselho Nacional do Meio Ambiente (CONAMA). Resolução n. 358, de 29 de abril de 2005 . Dispõe sobre o tratamento e a disposição final dos resíduos dos Serviços de Saúde e dá outras providências [Internet]. Brasília; 2005 [citado 2013 abr. 04]. Disponível em: http://www.mma.gov.br/port/conama/res/res05/res35805.pdf 